\title{
Variation in egg organic content and its relationship with egg size in the starfish Solaster stimpsoni
}

\author{
Larry R. McEdward \& Sally F. Carson \\ Department of Zoology, University of Alberta, Edmonton, Alberta T6G 2E9, Canada \\ and \\ Bamfield Marine Station, Bamfield, British Columbia V0R 1B0, Canada
}

\begin{abstract}
Mean size (volume) of the eggs of the starfish Solaster stimpsoni was $0.406 \mathrm{~mm}^{3}(\mathrm{n}=658)$; this did not differ among 4 locations in Barkley Sound, on the west coast of Vancouver Island, Canada. However, there were significant differences in mean egg size among females at each location. The range of egg sizes among siblings within a single spawn was 28 and $39 \%$ of the mean size for 2 females ( $\mathrm{n}=100$ for each sample). Egg organic content (measured for individual eggs) was also variable. Mean content was $113.9 \mu \mathrm{g}$ organic carbon $\mathrm{egg}^{-1}$. There were significant differences in egg organic content among locations and among females within a population. The range of sibling variation was 43 and $48 \%$ of the mean content. However, egg size was not a reliable predictor of egg content. Even the extreme egg sizes failed to yield significantly different predictions of egg content. Therefore the assumption that egg size is a reliable indicator of parental investment per offspring is not warranted in intraspecific life history studies.
\end{abstract}

\section{INTRODUCTION}

Egg size is probably the most frequently reported life history character for marine benthic invertebrates. Within the context of current life history theory, egg size is used as an indicator of parental investment. In other words, it is assumed that larger eggs contain more organic material. This is an important assumption for several reasons. (1) Organic content is difficult or impossible to measure non-destructively. (2) Egg size is strikingly correlated with other important life history traits such as fecundity, duration of the larval period, larval size, and mode of larval nutrition (e.g. Thorson 1936, 1946, 1950); there exists a large body of literature describing egg size and its interspecific variation and correlation with reproductive and developmental characteristics (e.g. Hadfield 1975, Hendler 1975, Rice 1975, Chia 1976, Hermans 1979, Reaka 1979, Sastry 1979, Hadfield \& Switzer-Dunlap 1984, Emlet et al. 1987). (3) In free-spawning species, there is no parental care after release of the gametes: fertilization and development occur in the seawater, and egg content therefore constitutes the entire contribution by the parent to the offspring. It is a biologically reason- able assumption that larger eggs should contaun more material. Clearly, this assumption is important for the integration of life history theory with the information on reproduction and development of marine invertebrates.

However, few studies have attempted to evaluate this assumption. Strathmann \& Vedder (1977) found that egg organic content was significantly correlated with egg size among species with small eggs, ranging in size from $\sim 50$ to $200 \mu \mathrm{m}$ in diameter. Organic content was not linearly related to egg size, rather it was proportional to a fractional power $(\sim 0.75)$ of egg volume. Turner \& Lawrence (1979) reported that the biochemical composition of echinoderm eggs (size range $\sim 70$ to $800 \mu \mathrm{m}$ diameter) was variable. In spite of these qualitative differences among species with different egg sizes, these data indicate that there is a rank correlation between egg size and total organic content.

Although both studies suggest that, among species, larger eggs have greater organic content, the reliability of egg size as an indicator of parental investment remains in question. Several important points remain unresolved. First, natural selection does not operate on 
the differences in parental investment between species. It operates on intraspecific variation. Are we warranted in applying the interspecific result and assuming that intraspecific differences in egg size reflect differences in organic content? Second, egg size and (in some cases) egg quality are known to be ecologically variable. Eggs differ with female nutritional state, water temperature, and latitude (e.g. Bayne et al. 1975, 1979, Thompson 1983). We simply do not have sufficient information to know how reproductive responses to ecological conditions influence the variation in egg size, egg quality, or their relationship. It is not clear whether mean size and content measured under one set of conditions can be applied to other (often unknown) conditions. Therefore, we do not know the minimum difference in egg size that allows a confident prediction of difference in egg content, even among species. Third, it is unclear whether the mea- surement of batches (thousands) of eggs can describe adequately the inherent variation within and among species.

The measurement of size and content of individual eggs was used recently (McEdward \& Coulter 1987 ) to overcome some of the problems associated with batch measurements and to evaluate the intraspecific relationship between egg size and content. In that study, we found that egg size and content varied considerably but were not correlated. The result was obtained for 2 species of starfish, Pteraster tesselatus and Henricia sp. (leviuscula?). However, it was limited to the comparison among sibling offspring from a single spawn obtained from one female of each species.

Here we report the results of an extensive study of the variation in egg size, individual egg content, and their relationship in the starfish Solaster stimpsoni. We found that egg size and content showed considerable

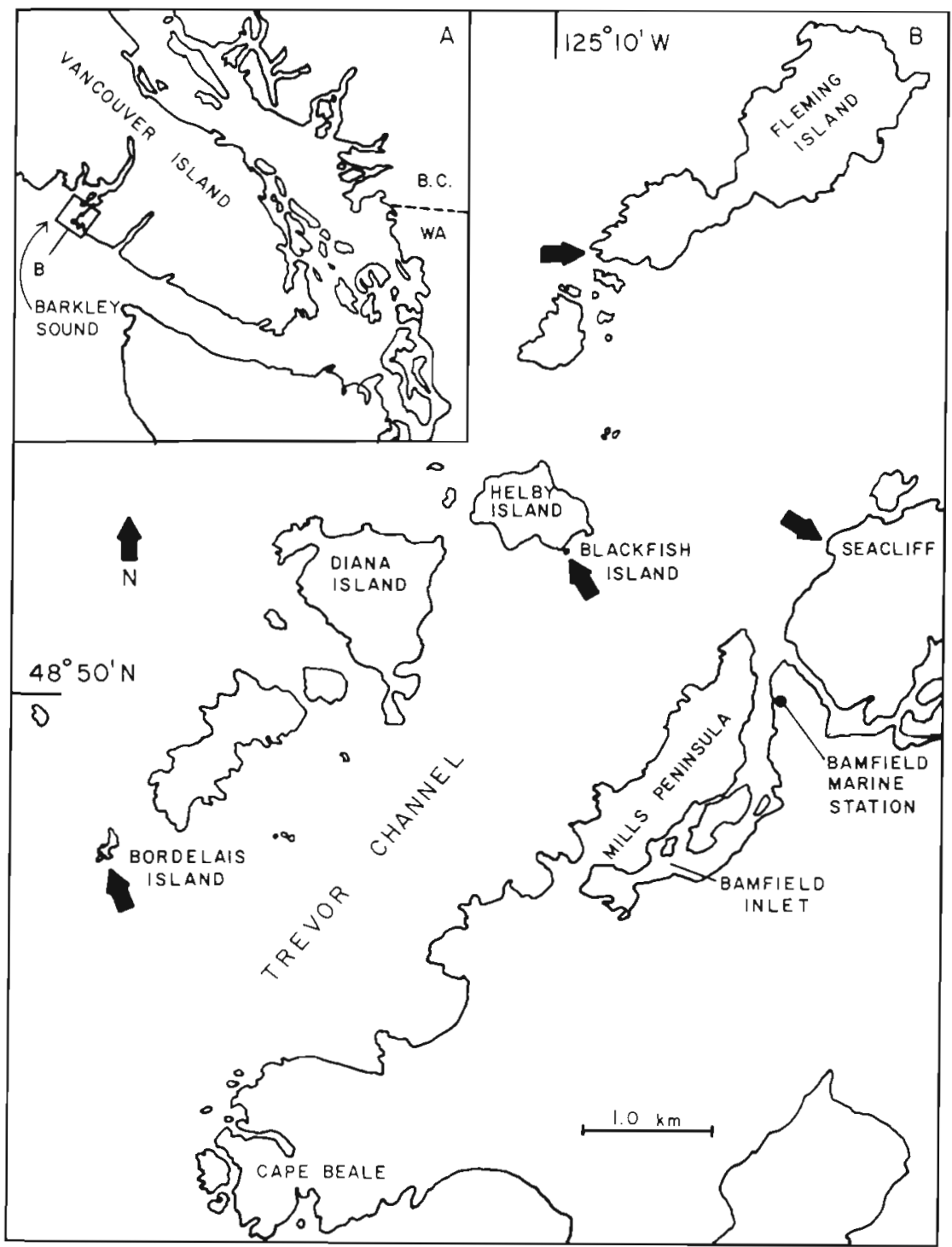

Fig. 1. Location of sites from which Solaster stimpsoni were collected 
Table 1. Characteristics of the locations from which aduits of Solaster stimpsoni were collected in Barkley Sound, Vancouver Island

\begin{tabular}{|c|c|c|c|c|}
\hline Characteristic & Blackfish & Seacliff & Fleming & Bordelais \\
\hline Depth (m) & $10-15$ & $7-15$ & $10-20$ & $15-25$ \\
\hline Wave exposure & Moderate & Moderate & High & Extremely high \\
\hline Substratum & Cobble & Cobble & Cobble & Continuous rock \\
\hline S. stimpsoni density (ind $\mathrm{m}^{-2}$ ) & 0.12 & 0.07 & 0.03 & 0.15 \\
\hline \multicolumn{5}{|l|}{ Adult size ( $R, \mathrm{~mm})$} \\
\hline Mean & 189 & 201 & 188 & 149 \\
\hline $\mathrm{SD}$ & 25 & 47 & 40 & 19 \\
\hline $\mathrm{n}$ & 27 & 42 & 38 & 50 \\
\hline
\end{tabular}

variation at all levels of intraspecific comparison: among sibling offspring within the spawn of a single female, among females within a single population, and among populations (localities). Furthermore we concluded that in contrast to the species trends, and the assumptions made in life history studies, but in agreement with our previous results, egg size is not a reliable predictor of intraspecific differences in egg organic content.

\section{METHODS}

Solaster stimpsoni Verrill 1878 (Order Spinulosida) is a common subtidal starfish in the northern Pacific Ocean. Aduits were coliected using SCUBA from Á locations in Barkley Sound on the west coast of Vancouver Island, British Columbia, Canada $\left(48^{\circ} 49^{\prime} \mathrm{N}\right.$, $125^{\circ} 08^{\prime} \mathrm{W}$ ). The collection sites were at Seacliff, Blackfish Island, Fleming Island, and Bordelais Island (Fig. $1_{i}$ see Table 1 for comparison of sites).

Adults were maintained in running seawater in the lab. The sea cucumber Cucumaria miniata was provided as food. The starfish were measured and tagged for later identification. In most cases, spawning was induced within 1 to $3 \mathrm{~d}$ following collection.

Spawning was induced by injection of $1 \mathrm{ml}$ of $10^{-4}$ M 1-methyl adenine (Kantani 1973, 1975) into the base of each ray and $3.5 \mathrm{ml}$ into the body cavity of the disk. Eggs were generally released within 8 to $14 \mathrm{~h}$ after injection.

Egg volume was calculated using the formula

$$
\text { Volume }=(4 / 3) \pi\left(\frac{D_{1}}{2}\right)\left(\frac{D_{2}}{2}\right)\left(\frac{D_{3}}{3}\right)
$$

from 3 perpendicular diameters $\left(D_{1}, D_{2}, D_{3}\right)$ measured with an ocular micrometer on a stereomicroscope (magnification $25 \times$ ). The ocular micrometer limited the resolution of differences in volume to $\sim 0.018 \mathrm{~mm}^{3}$.

The eggs were oblate spheroids of variable shape, the animal-vegetal diameter being significantly shorter than the equatorial diameters, but bearing no consistent relationship to them. The animal-vegetal diameter could not be predicted with confidence from either the greatest equatorial diameter (95\% confidence interval around the prediction $=180 \mu \mathrm{m}=21 \%$ of mean) nor the average of the 2 equatorial diameters (95\% confidence interval around the prediction = $190 \mu \mathrm{m}=22 \%$ of mean) (see Table 6). It was necessary to suspend the eggs in a viscous medium (Protoslo, Carolina Biological Co.) to orient them for measurement of the animal-vegetal diameter. Eggs were held in filtered seawater, individually transferred to Protoslo, measured, then transferred to individual containers with filtered seawater. The eggs were subsequently washcd through 3 changes of filtered seawater $(500 \mathrm{ml})$ to remove the Protoslo. Treatment with Prototslo did not influence the measurement of organic content (mean content with Protoslo treatment $=92.2 \mu \mathrm{g} \mathrm{C}$, $\mathrm{n}=20$; mean content without Protoslo treatment $=$ $92.2 \mu \mathrm{g} \mathrm{C}, \mathrm{n}=10 ; \mathrm{t}=0.0, \mathrm{p}>0.05$ ).

Organic content was measured by dichromate oxidation against a glucose standard ( 0 to $300 \mu \mathrm{g}$ ) using a micro-modification of the procedure described by Parsons et al. (1984). Each egg was washed briefly in distilled water $(\sim 10 \mathrm{~s})$ to remove salts. Washing did not cause egg rupture. Given the stability of eggs in distilled water (>5 min), leakage of egg contents was assumed to be negligible. The eggs were incubated in concentrated $(70 \%)$ phosphoric acid $(1 \mathrm{ml}, 15 \mathrm{~min}$, $110^{\circ} \mathrm{C}$ ) to remove residual chloride, then oxidized with potassium dichromate $(0.484 \%)$ in concentrated sulpuric acid ( $2 \mathrm{ml}, 15 \mathrm{~min}, 110^{\circ} \mathrm{C}$ ). Reduction in dichromate concentration indicates the amount of organic carbon oxidized. Samples were diluted $(3.5 \mathrm{ml}$ distilled water) and measured spectrophometrically (440 nm, 1 $\mathrm{cm}$ path length). Organic content was reported as the weight of glucose $(\mu \mathrm{g})$ yielding equivalent reduction in dichromate concentration. The resolution of the assay was $\sim 5 \mu \mathrm{g} \mathrm{C}$. Organic carbon can be converted to total 
organic matter by the formula: $1 \mu \mathrm{g} \mathrm{C}=2.5 \mu \mathrm{g} \mathrm{OM}$, based on the proportion of glucose molecular weight represented by carbon (e.g. Strathmann \& Vedder 1977). Organic carbon can be converted to joules by the formula: $1 \mu \mathrm{g} \mathrm{C}=3.90 \times 10^{-2} \mathrm{~J}$, based on constants in Parson et al. (1984).

A total of 658 eggs from 25 females from the 4 populations were measured (Table 2) between 11 and 24 March 1986. Three levels of comparison were made using these data: (1) overall trends among locations; (2) among females at the Seacliff location; and (3) among eggs within the spawn of individual females at the Seacliff location (SC-A, SC-B).

Table 2. Sampling and measurement design

\begin{tabular}{lcccc|}
\hline Location & $\begin{array}{c}\text { No. of } \\
\text { females }\end{array}$ & Label & $\begin{array}{c}\text { No. eggs } \\
\text { female }\end{array}$ & $\begin{array}{c}\text { Total no. } \\
\text { of eggs }\end{array}$ \\
\hline Blackfish & 5 & BF 1-5 & $20^{\circ}$ & 99 \\
Seacliff & 8 & SC 1-8 & $20^{\circ}$ & 359 \\
& 2 & SC-A, SC-B & 100 & 100 \\
Fleming & 5 & FL 1-5 & 20 & 100 \\
Bordelais & 5 & BD & 20 & 658 \\
Total & 25 & - & - & \\
- 1 egg missing from these samples & & \\
\multicolumn{7}{l}{}
\end{tabular}

Regression and correlation analyses followed procedures in Zar (1974). Confidence belts (prediction intervals) were constructed for the regressions by calculating the $95 \%$ confidence intervals around the predicted values of the dependent variable (Y). The confidence intervals were calculated for the predicted $Y$ that would be obtained from a single additional measurement of the independent variable (X) (Zar 1974, p. 212, Eqn 16.27). The confidence belts were con- structed from confidence intervals around predicted $\mathrm{Y}$ calculated for 10 arbitrary values of $X$ spanning the measured range of $X$ in the sample. The usefulness of the regression for predictions was determined by calculating the minimum difference in $\mathrm{X}$ that would avoid overlap of the $95 \%$ confidence intervals for the predicted values of $Y$. The difference in $X$ values was distributed symmetrically around the mean value of $X$ to compensate for the slight curvilinearity of the confidence belts, in effect biasing the result in favor of minimum differences in $\mathrm{X}$.

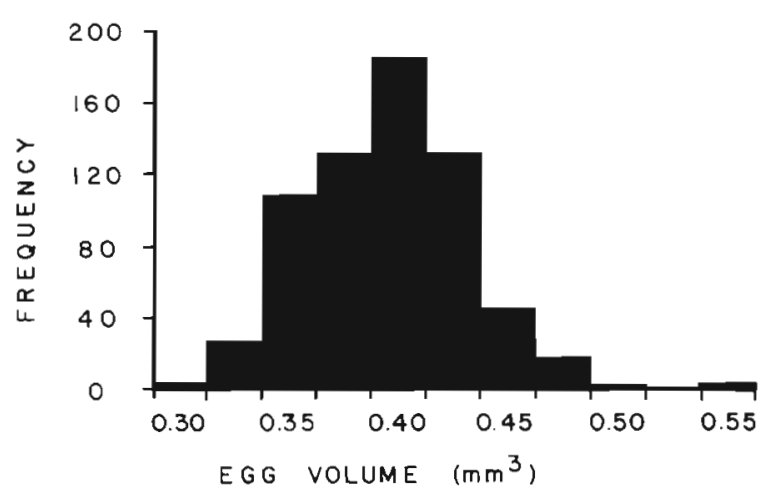

Fig. 2. Solaster stimpsoni. Frequency histogram of egg volumes for the entire sample $(n=658)$ of eggs

Analysis of variance testing utilized an SPSS-x user procedure, UANOVA, developed at the University of Alberta Computing Services. UANOVA is a 1 -way ANOVA for nested designs with unequal sample sizes, and includes multiple comparison testing. Analysis of variance was calculated with both unique and hierarchical sums of squares. The results were the same (no qualitative differences), therefore only the hierarchical model is reported. All hypothesis testing was done at the $5 \%$ significance level.

Table 3. Solaster stimpsoni. Mean egg size, organic content, and organic density of eggs. n: sample size; CI: confidence interval; CV: \% coefficient of variation

\begin{tabular}{|c|c|c|c|c|c|c|c|c|c|c|}
\hline & \multirow[b]{2}{*}{$\mathrm{n}$} & \multicolumn{3}{|c|}{ Volume } & \multicolumn{3}{|c|}{ Content } & \multicolumn{3}{|c|}{ Density } \\
\hline & & $\begin{array}{c}\text { Mean } \\
\left(\mathrm{mm}^{-3}\right)\end{array}$ & $\begin{array}{c} \pm 95 \% \\
\mathrm{CI}\end{array}$ & $\mathrm{CV}$ & $\begin{array}{c}\text { Mean } \\
\left(\mu \mathrm{g} \mathrm{egg}^{-1}\right)\end{array}$ & $\begin{array}{c} \pm 95 \% \\
\mathrm{CI}\end{array}$ & $\mathrm{CV}$ & $\begin{array}{c}\text { Mean } \\
\left(\mu \mathrm{g} C \mathrm{~mm}^{-3}\right)\end{array}$ & $\begin{array}{c} \pm 95 \% \\
\mathrm{CI}\end{array}$ & $\mathrm{CV}$ \\
\hline Overall & 658 & 0.406 & 0.003 & $9.1 \%$ & 113.9 & 1.4 & $16.1 \%$ & 281.2 & 3.3 & $15.5 \%$ \\
\hline \multicolumn{11}{|l|}{ Locations } \\
\hline Blackfish & 99 & 0.411 & 0.007 & $8.8 \%$ & 94.1 & 5.0 & $26.9 \%$ & 228.7 & 11.8 & $25.8 \%$ \\
\hline Seacliff & 359 & 0.412 & 0.004 & $9.0 \%$ & 119.0 & 1.4 & $11.7 \%$ & 289.6 & 3.2 & $10.6 \%$ \\
\hline Fleming & 100 & 0.402 & 0.007 & $8.3 \%$ & 120.1 & 2.4 & $10.2 \%$ & 298.8 & 3.6 & $6.0 \%$ \\
\hline Bordelais & 100 & 0.384 & 0.007 & $9.4 \%$ & 108.6 & 2.7 & $12.5 \%$ & 285.3 & 8.9 & $15.8 \%$ \\
\hline \multicolumn{11}{|l|}{ Females } \\
\hline SC-A & 100 & 0.439 & 0.006 & $7.3 \%$ & 119.4 & 1.7 & $7.3 \%$ & 275.3 & 4.8 & $8.8 \%$ \\
\hline SC-B & 100 & 0.408 & 0.005 & $5.6 \%$ & 129.0 & 1.9 & $7.6 \%$ & 316.0 & 3.8 & $6.0 \%$ \\
\hline
\end{tabular}




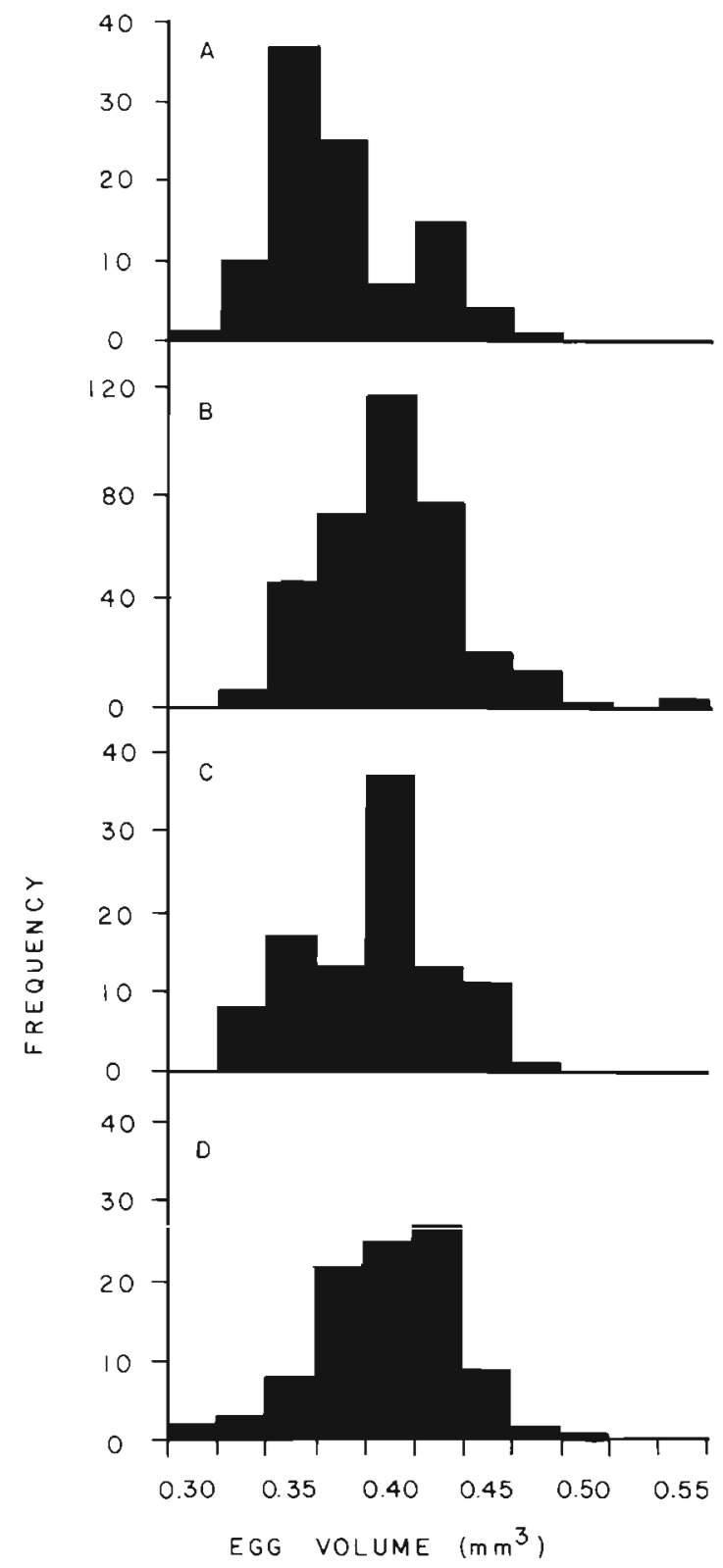

Fig. 3. Solaster stimpsoni. Frequency histograms of egg volumes from each location. (A) Blackfish Island ( $\mathrm{n}=99$ ); (B) Seacliff $(n=359)$; (C) Fleming Island $(n=100)$; (D) Bordelais Island $(\mathrm{n}=100)$

\section{RESULTS}

\section{Variation in egg size}

Egg volume for the entire sample of 658 eggs was normally distributed around the mean of $0.406 \mathrm{~mm}^{3}$ (Fig. 2, Table 3). Mean egg volumes were not significantly different among the 4 locations (Table 3 , UANOVA $F=1.12, p>0.05$ ). The distribution of egg sizes at each location was similar to the overall dis- tribution (Fig. 3). At every location, there were significant differences among females (UANOVA multiple comparison). The distribution and variation in egg sizes among siblings within the spawn of a female (SCA, SC-B) were approximately the same as that among females at a location or overall (Table 3; Fig. 4).

\section{Variation in egg organic content}

The mean organic content was $113.9 \mu \mathrm{g} \mathrm{C} \mathrm{egg}{ }^{-1}$ (Table 3). The distribution was skewed towards eggs of low organic content (Fig. 5). Mean egg content was not

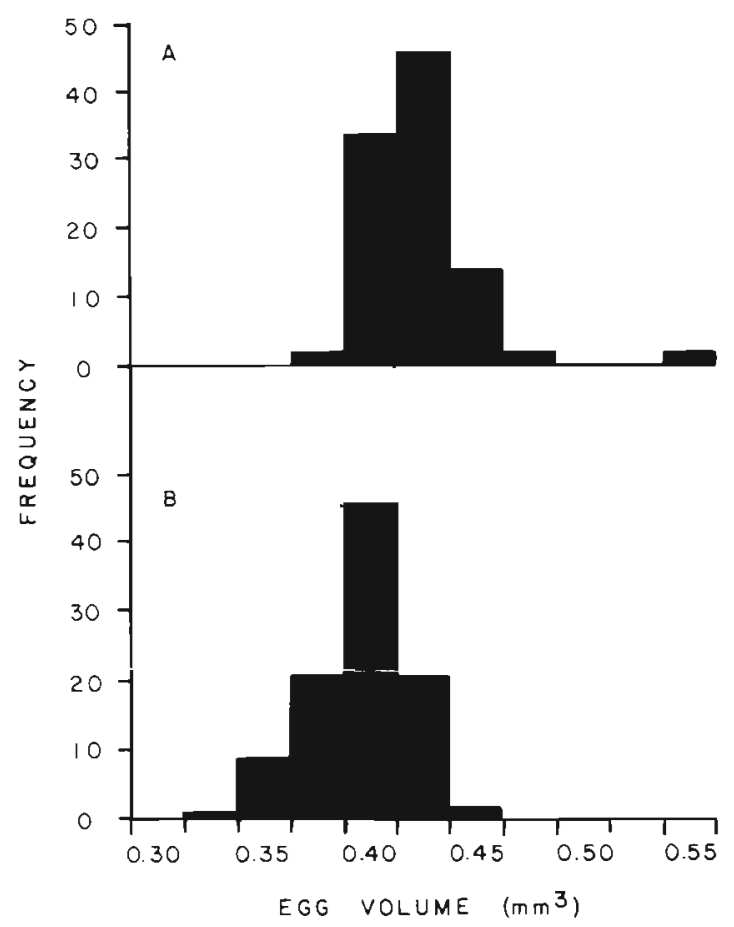

Fig. 4. Solaster stimpsoni. Frequency histograms of egg volume for 2 females from Seacliff. (A) SC-A $(n=100)$; (B) SC-B $(\mathrm{n}=100)$

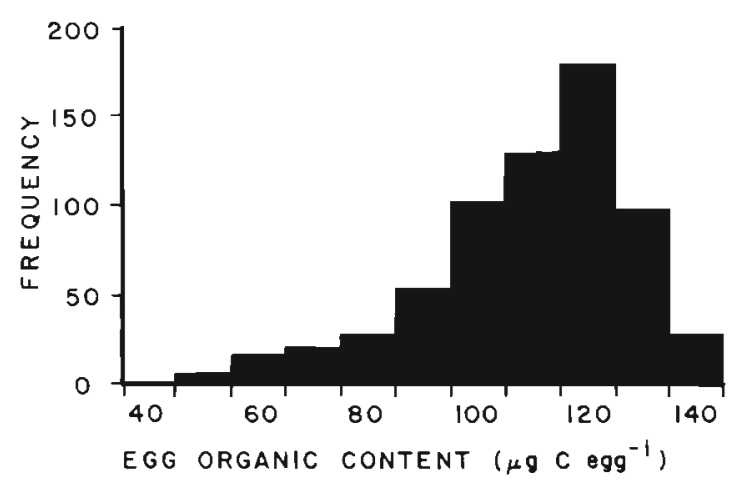

Fig. 5. Solaster stimpsoni. Frequency histogram of egg organic content for the entire sample ( $n=658$ ) of eggs 


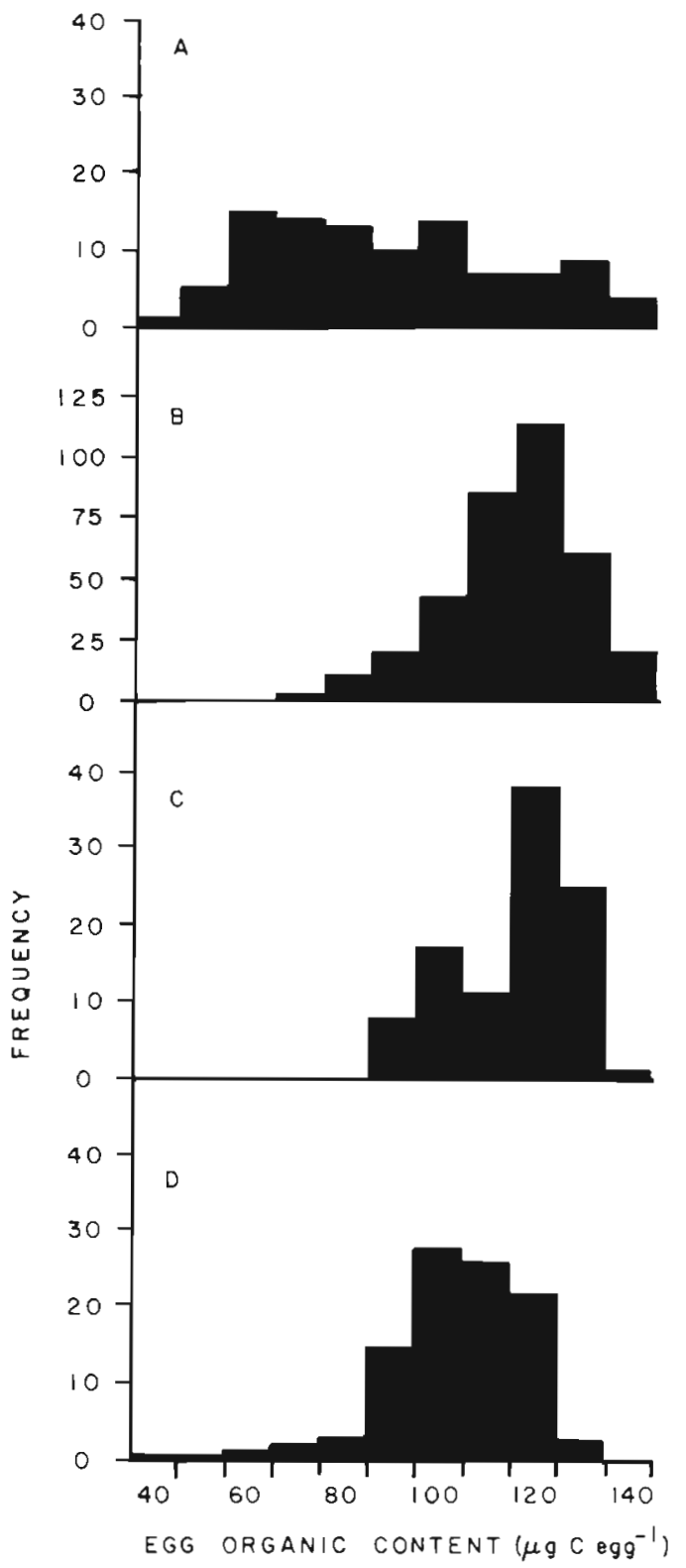

Fig. 6. Solaster stimpsoni. Frequency histograms of egg organic contents from each location. (A) Blackfish Island ( $\mathrm{n}=$ 99); (B) Seacliff $(n=359)$; (C) Fleming Island ( $n=100)$; (D) Bordelais Island $(n=100)$

the same at all locations, Blackfish being significantly lower than the other 3 locations (Table 3, UANOVA multiple comparison). A substantial fraction $(35 \%)$ of the eggs at Blackfish had organic contents less than $80 \mu \mathrm{g} \mathrm{C}$ (< overall mean - 2 SDs). No other location had more than $3 \%$ of the eggs below $80 \mu \mathrm{g} \mathrm{C}$. The distribution of Blackfish was platykurtic with a high coefficient of variation $(26.9 \%)$ compared to the other locations (Fig. 6). The distributions of egg content at the remaining locations showed variable degrees of skew towards low organic content, similar to the dis-

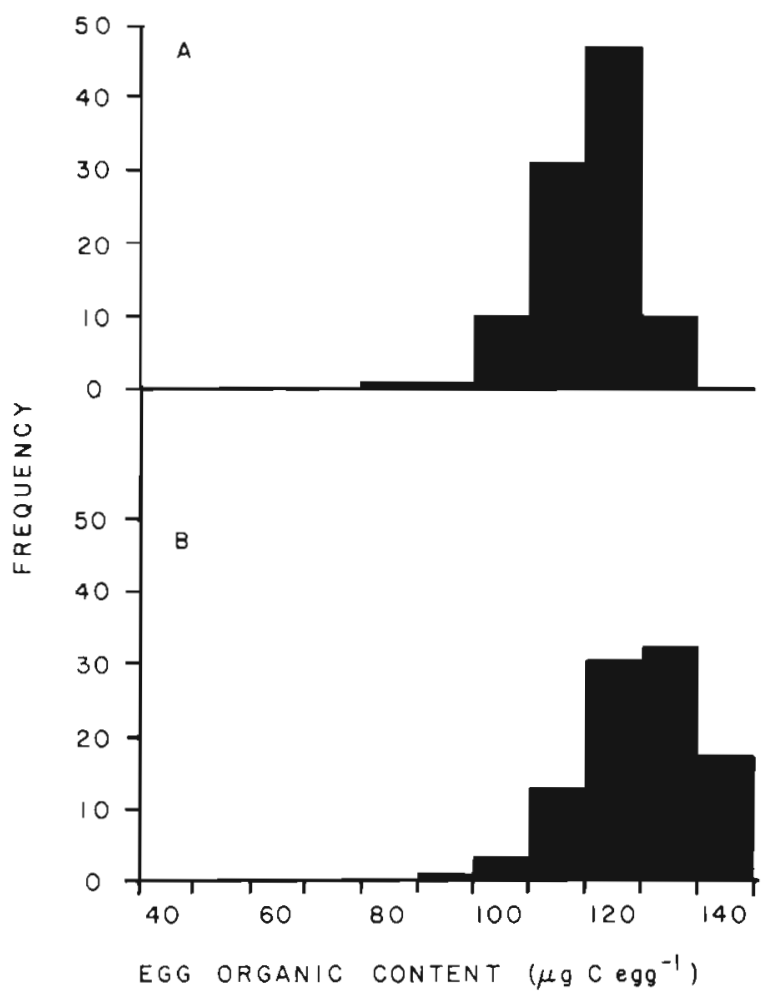

Fig. 7. Solaster stimpsoni. Frequency histograms of egg organic content for 2 females from Seacliff. (A) SC-A (n = $100) ;(B) S C-B(n=100)$

tribution for the entire sample. At every location, there were significant differences in the mean organic contents among females (UANOVA multiple comparison). There was less variation among the eggs produced by individual females at Seacliff (SC-A, SC-B) compared to the variation for all females at that location (Fig. 7; Table 3). However, there was considerable variation among the eggs for each female. The range of egg contents were $48 \%$ (SC-A) and $43 \%(\mathrm{SC}-\mathrm{B})$ of the mean content.

\section{Variation in egg organic density}

Organic density (= organic concentration) is the organic content per unit volume. The mean organic density for the entire sample was $281.2 \mu \mathrm{g} \mathrm{C} \mathrm{mm} \mathrm{mm}^{-3}$ (Table 3). There was considerable variation in organic density among locations but only Blackfish and Fleming were statistically different (UANOVA multiple comparison) because there was much variation among females at all locations (Table 3 ). The mean organic densities of eggs from 2 individuals (SC-A, SC-B) were significantly different $(t=13.21, p<0.05)$ from each other and were somewhat less variable than among locations. 
Fig. 8. Solaster stimpsoni. Scatter plot of egg organic content against egg volume for the entire sample $(n=658)$ of eggs. Upper and lower lines indicate $95 \%$ confidence interval for predicted content. Center line is the least-square linear regression

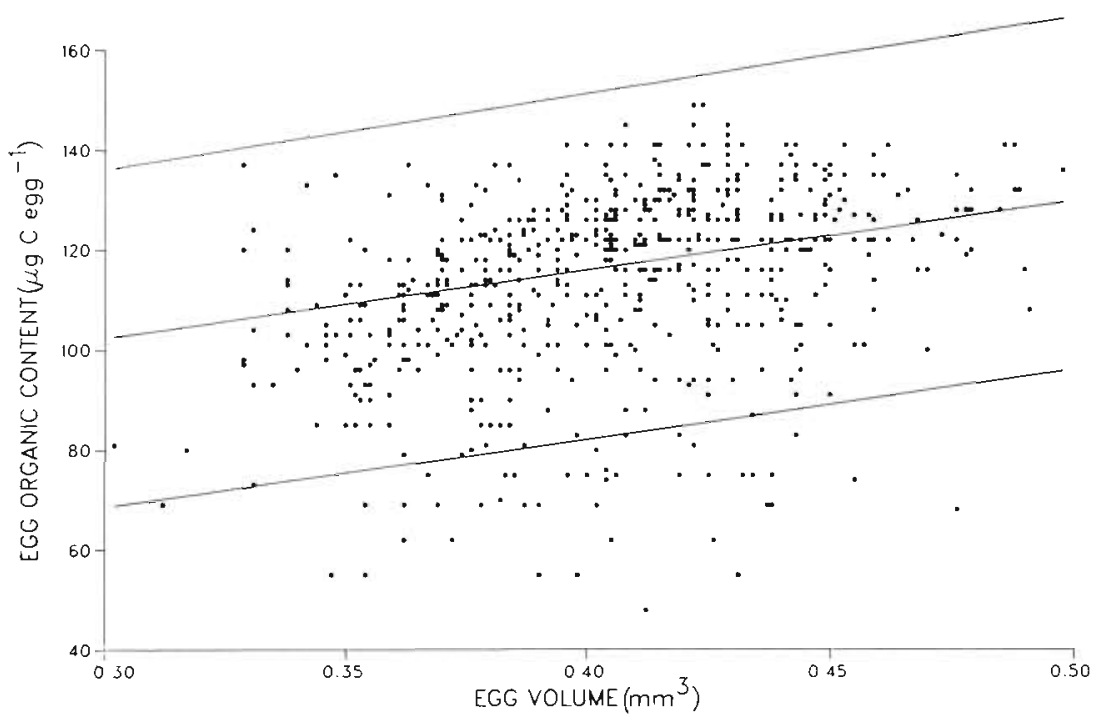

\section{Relation between egg size and organic content}

There is a significant, positive correlation between egg volume and organic content for the entire sample of 658 eggs from the 25 females at the 4 locations $(r=0.34)$. The regression of content on volume explains $12 \%$ of the variance in content (Table 4; Fig 8). The minimum and maximum egg volumes obtained in the sample do not predict significantly different egg contents. There is overlap of the $95 \%$ confidence intervals around the egg contents predicted from all sizes of eggs including the extreme egg sizes (Table 4; Fiq. 8). The regression of content on volume for the mean values of the 25 females explains no more of the variation in content $(12 \%)$ and does not yield a more effective prediction of organic content from egg size (Table 4 ; Fig. 9).

The same relations hold among females at the Seacliff location (Fig. 10). Egg content is significantly correlated with egg volume and volume explains $22 \%$ of the variance in egg content (Table 4). The regression equation for the Seacliff location is not significantly different from the overall regression (slope, $t=0.256$ $\mathrm{p}>0.05$; intercept, $\mathrm{t}=0.229 \mathrm{p}>0.05$ ). The extreme

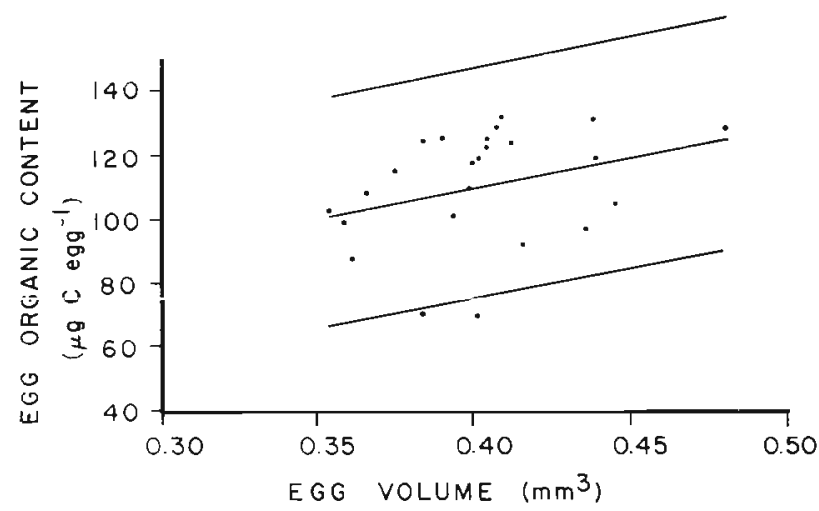

Fig. 9. Solaster stimpsoni. Scatter plot of mean egg organic content against mean egg volume for 25 females. Upper and lower lines indicate $95 \%$ confidence interval for predicted content. Center line is the least-square linear regression

Table 4. Solaster stimpsoni. Regression equation for egg size and organic content. $\mathrm{n}$ : = sample size; Cl: confidence interval; ns: not significant. Xpredict $Y$ is the difference in volume $(X)$ necessary to result in predicted contents $(Y)$ for which the $95 \%$ confidence intervals do not overlap. The difference in volume is expressed as a percentage of the range in volume measured for the sample

\begin{tabular}{|lccccccc|}
\hline Group & $\mathrm{n}$ & Intercept & Slope & $\pm 95 \% \mathrm{CI}$ & $\mathrm{r}^{2}$ & Slope $=0$ ? & XpredictY \\
\hline $\begin{array}{l}\text { Overall } \\
\text { (eggs) }\end{array}$ & 658 & 44.9 & 169.7 & 35.2 & 0.12 & $\mathrm{p}<0.05$ & $>100 \%$ \\
$\begin{array}{l}\text { Overall } \\
\quad \text { female means) }\end{array}$ & 25 & 30.3 & 199.8 & 235.8 & 0.12 & $\mathrm{p}>0.05$ (ns) & $>100 \%$ \\
Seacliff & 359 & 46.0 & 177.3 & 34.6 & 0.22 & $\mathrm{p}<0.05$ & $>100 \%$ \\
SC-A & 100 & 104.3 & 34.3 & 54.8 & 0.02 & $\mathrm{p}>0.05$ (ns) \\
SC-B & 100 & 21.8 & 262.4 & 65.2 & 0.39 & $\mathrm{p}<0.05$ & $>100 \%$ \\
\end{tabular}




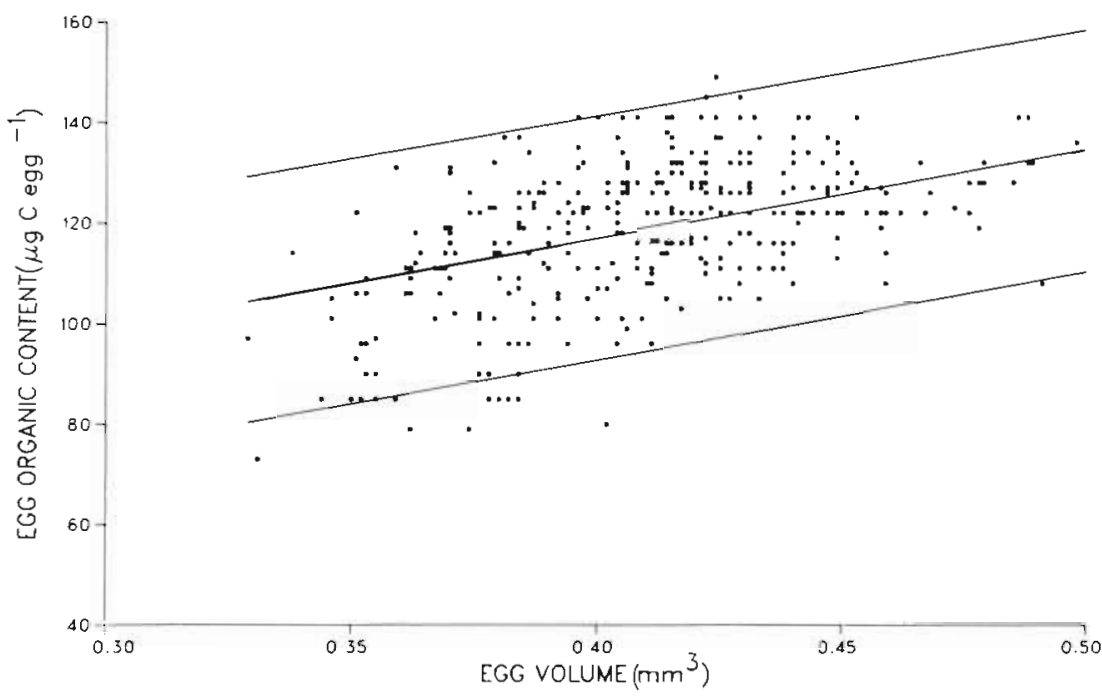

Fig. 10. Solaster stimpsoni. Scatter plot of egg organic content against egg volume for females from the Seacliff location (n = 359). Upper and lower lines indicate $95 \%$ confidence interval for predicted content. Center line is the leastsquare linear regression egg sizes do not yield significantly different predictions for egg organic content (Table 4; Fig. 10).

The relation between egg size and content among eggs from a single spawn was strikingly different for the 2 females, SC-A and SC-B, from the Seacliff location. There was no correlation between size and content for SC-A (Fig. 11). The slope of the regression line was not significantly different from zero (Table 4). However the regression of content on volume for the other females (SC-B) was significant and explained a substantial percentage of the variance in content (39\%; Table 4; Fig. 12). Extreme egg sizes failed to predict significantly different egg contents in both cases.

\section{Relation between egg size and organic density}

There was not a strong correlation between organic density and egg size except for one of the females from Seacliff (SC-A). The slope of the regression for the

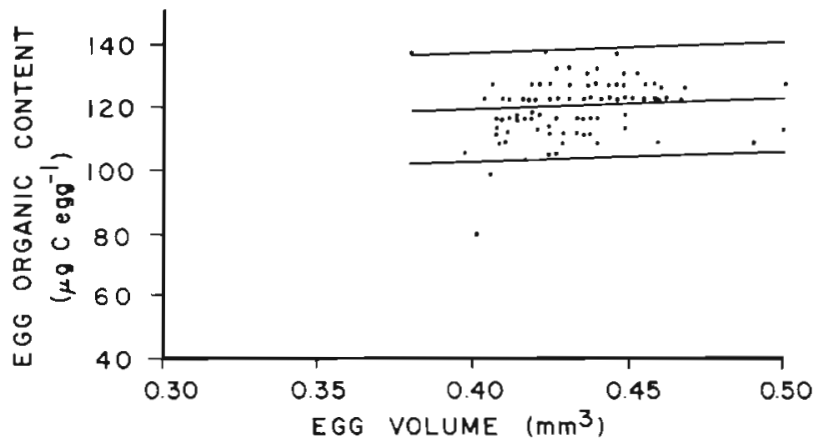

Fig. 11. Solaster stimpsoni. Scatter plot of egg organic content against egg volume for the eggs $(n=100)$ of one female (SCA) from Seacliff. Upper and lower lines indicate $95 \%$ confidence interval for predicted content. Center line is the leastsquare linear regression entire sample calculated for all eggs was negative and significantly different from zero (Table 5). The same result was obtained for the entire Seacliff location and for Female SC-B at Seacliff. The relation with egg size explained between 2 and $6 \%$ of the variance in organic density. Female SC-A showed a significant, negative relation between density and egg size that explained $30 \%$ of the variance in organic density (Table 5). However the fact that both measures (egg size and organic density) involve egg volume could lead to a spurious correlation. Since large eggs from this female did not contain more organic material than small eggs (Table 4; Fig. 11), then large eggs must contain less organic material per unit volume.

\section{DISCUSSION}

The present results clearly show that egg size is not a reliable indicator of egg organic content in Solaster stimpsoni. The same result was obtained for single

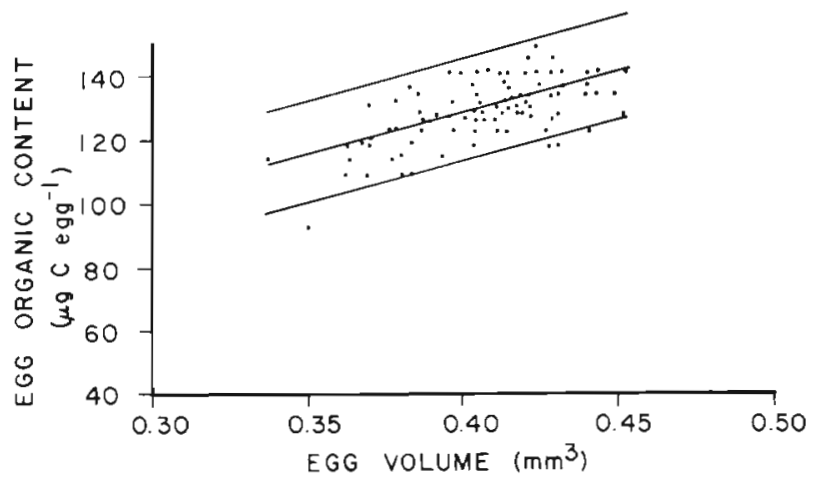

Fig. 12. Solaster stimpsoni. Scatter plot of egg organic content against egg volume for the eggs ( $n=100$ ) of one female (SCB) from Seacliff. Upper and lower lines indicate $95 \%$ confidence interval for predicted content. Center line is the leastsquare linear regression 
Table 5. Solaster stimpsoni. Regression equation for egg size and organic density. $\mathrm{n}$ : = sample size; $\mathrm{CI}$ : confidence interval; ns: not significant. XpredictY is the difference in volume $(\mathrm{X})$ necessary to result in predicted densities (Y) for which the $95 \%$ confidence intervals do not overlap. The difference in volume is expressed as a percentage of the range in volume measured for the sample

\begin{tabular}{lccccccc|}
\hline Group & $\mathrm{n}$ & Intercept & Slope & $\pm 95 \% \mathrm{CI}$ & $\mathrm{r}^{2}$ & Slope $=0$ ? & XpredictY \\
\hline $\begin{array}{l}\text { Overall } \\
\quad \text { (eggs) }\end{array}$ & 658 & 379.0 & -241.0 & 87.3 & 0.04 & $\mathrm{p}<0.05$ & $>100 \%$ \\
$\begin{array}{l}\text { Overall } \\
\text { (female means) }\end{array}$ & 25 & 344.3 & -169.3 & 581.2 & 0.02 & $\mathrm{p}>0.05(\mathrm{~ns})$ & $>100 \%$ \\
Seacliff & 359 & 373.6 & -203.9 & 84.0 & 0.06 & $\mathrm{p}<0.05$ & $>100 \%$ \\
SC-A & 100 & 456.9 & -413.6 & 125.6 & 0.30 & $\mathrm{p}<0.05$ & $>100 \%$ \\
SC-B & 100 & 366.5 & -123.7 & 161.9 & 0.02 & $\mathrm{p}>0.05$ (ns) & $>100 \%$ \\
\hline
\end{tabular}

females of the starfish Pteraster tesselatus (McEdward \& Coulter 1987) and Henricia sp. (McEdward \& Coulter unpubl.). Together these studies on species with large yolky eggs seriously question the validity of assuming that larger eggs represent greater parental investment. It is possible that in species with small eggs, size, content, and density are less variable and yield better predictions, but this has yet to be demonstrated. Nevertheless, the generality and robustness of the results with large eggs puts the burden of proof on the investigator who uses egg size to predict organic content in intraspecific comparisons.

There are important implications of this result for the study of life histories in marine invertebrates. Egg size, the most frequently reported life history character, cannot be used to estimate intraspecific variation in parentai investment. Consequentiy, there is not a rellable, non-destructive index of egg organic content. It will be difficult to analyze the relation between parental investment and the larval features that determine survival and therefore offspring fitness.

Significance of the regression slope is not a sufficient criterion for evaluating the predictive value of a relation. In several cases the regression of egg content on egg volume was statistically significant. However, there was considerable variation in content that was not explained by the relation with egg size (Table 4). The usefulness of the regression for prediction can be determined by using $95 \%$ confidence belts, or prediction intervals, around the regression (Zar 1974). These intervals are sensitive to the number of measurements upon which the prediction is based. The confidence belts will be quite narrow for the predicted mean obtained from a very large sample of eggs with a given volume (Zar 1974, p. 210, Eqn 16.24). But the prediction of interest here is for individual eggs. Given an egg of volume $X$, what is the range of contents within which the true content ( $Y$ ) falls (at the $95 \%$ probability level)? This range can be approximated by

$$
\pm \mathrm{CI}=\mathrm{t} \sqrt{\operatorname{Var} Y\left(1-\mathrm{r}^{2}\right)}
$$

where $\pm \mathrm{CI}=$ the $95 \%$ confidence interval; $\mathrm{t}=$ the tabulated $t$ value for the given significance level and for the degrees of freedom for the original regression; VarY $=$ the variance in the dependent variable; and $\left(1-r^{2}\right)=$ the coefficient of non-determination (i.e. the proportion of the variance in $Y$ that is not explained by the regression). The exact equation for the $95 \%$ confidence interval is given by $\mathrm{Zar}$ (1974, p. 212, Eqn 16.27).

Using the $95 \%$ confidence belts for the regression, it is possible to calculate the minimum difference in volume between 2 eggs that yields significantly different predictions for the organic contents of those eggs. Significance is here defined by non-overlap of the $95 \%$ confidence interval around the predicted content. The minimum required difference in egg size is influenced by the regression slope, the variance in content, and the proportion of the variance that is explained by the regression. In all cases in the present study, even the extreme egg sizes failed to yield significantly different egg contents (Table 4). It is on this basis that we conclude that egg size is not a reliable indicator of egg organic content.

An additional limitation on the use of egg dimensions in life history studies on Solaster stimpsoni (and probably many other species with large yolky eggs) results from the spheroidal shape of the eggs. There is a poor relation between egg diameter measured in the equatorial plane and diameter measured along the animal-vegetal axis (Table 6). It is necessary to measure 3 mutually perpendicular diameters to obtain reasonable estimates of egg volume without systematic error. It is unlikely that good estimates of volume can be calculated from published egg sizes reported as a single measured diameter, except in the case of species with very small spherical eggs.

\section{Variation in egg size, content, and density}

There was a wide range of egg sizes among sibling offspring (i.e. within a spawn) from both females, SC-A 
Table 6. Solaster stimpsoni. Shape characteristics of eggs Sample of 25 eggs from 1 female. EQ1: greatest equatorial diameter; EQ2: equatorial diameter perpendicular to EQ1; Mean $\mathrm{EQ}=(\mathrm{EQ} 1+\mathrm{EQ} 2) / 2 ; \mathrm{AV}$ : animal-vegetal diameter Mean values $(\mu \mathrm{m})$. SD: standard deviation; CV: \% coefficient of variation; $\mathrm{CI}: 95 \%$ confidence interval

\begin{tabular}{|c|c|c|c|c|c|}
\hline & EQ1 & EQ2 & AV & $\mathrm{AV} / \mathrm{EQ} 1$ & $\begin{array}{c}\mathrm{AV} / \\
\text { Mean EQ }\end{array}$ \\
\hline Mean & 1014.4 & 964.8 & 870.4 & 0.86 & 0.89 \\
\hline SD & 56.4 & 61.5 & 50.7 & 0.09 & 0.08 \\
\hline $\mathrm{CV}$ & $5.6 \%$ & $6.4 \%$ & $5.8 \%$ & $10.2 \%$ & $9.2 \%$ \\
\hline \multicolumn{4}{|c|}{ Regression equation } & $\mathrm{I}^{2}$ & $95 \% \mathrm{CI}$ \\
\hline \multicolumn{4}{|c|}{$\mathrm{AV}=1334.3-0.457(\mathrm{EQ} 1)$} & 0.26 & \pm 90.2 \\
\hline \multicolumn{4}{|c|}{$A V=1310.4-0.446($ Mean EQ $)$} & 0.18 & \pm 95.0 \\
\hline
\end{tabular}

and SC-B. The range was 39 and $28 \%$ of the mean respectively for these females. Likewise, there was substantial variation in egg organic content. The ranges for females SC-A and SC-B were, respectively, 48 and $43 \%$ of the mean egg content. This variation was measured in a sample of 100 eggs that represents no more than 1 to $2 \%$ of the total spawn. Clearly, in the entire spawn, a large number of eggs will differ substantially from the mean size and content.

This variation among siblings produced at the same time may reflect imprecision inherent in starfish gametogenesis or it may be an adaptive response to variation in the larval or juvenile environment. At present there is insufficient evidence to decide between these alternatives.

The distribution of egg contents showed varying degrees of skew towards low organic content (Fig. 5, 6 $\& 7$ ). This could indicate that hormonally-induced spawning caused release of eggs that had not completed vitellogenesis. If so, then some of the variation observed in our samples was artificial. This argument assumes that, even though vitellogenesis may occur asynchronously throughout the gonad, eventually the population of gametes comes to be normally distributed around some predetermined mean content, at which time natural spawning becomes possible. We do not know of any measurements of the changes in egg content during vitellogenesis. In any case, several points suggest that our results are not entirely artificial.

First, the results of McEdward \& Coulter (1987), obtained for a spontaneous spawn of Pteraster tesselatus, support the present results. Second, it is not known what stimuli induce spawning in nature. Evidence suggests that gamete release often follows stress (e.g. high temperature, wave shock; e.g. Giese 1959, Giese \& Pearse 1974). The timing of gamete release probably can be highly variable with respect to attainment of ripeness. Therefore, if variation exists during the maturation of the gamete population, it is likely that that such variation is often present at the time of natural spawning. Finally, induction of spawning with 1 -methyl adenine is successful only with ripe animals. It is an accepted technique that provides healthy, fertilizable eggs (Kanatani 1973, 1975). If it introduces a small artificial component to the variation in egg size and content, such artificial variation will also exist in all samples of eggs obtained via hormonal induction. It is therefore appropriate, for practical considerations, to evaluate the predictive relation between egg size and content in samples that include this variance component.

In summary, the eggs of Solaster stimpsoni vary in size and organic content among siblings within a spawn, among females from the same population, and among locations. Although egg content is often significantly correlated with egg size, egg size is not a reliable predictor of egg quality (and therefore parental investment) for intraspecific life history studies. These results challenge a fundamental assumption in reproductive biology and increase the difficulty of elucidating the evolutionary tradeoffs that underly the life history patterns of marine invertebrates.

Acknowledgements. We thank R. Foreman, Director, for providing space and facilities at the Bamfield Marine Station. D. Duncan, S. Rumrill, and several anonymous reviewers provided constructive criticism of earlier drafts of the manuscript. T. Taerum provided much valuable advice with statistics. Financial support was provided through a University of Alberta Central Research Fund Operating grant to L. McEdward, an Izaak W. Killam post-doctoral fellowship to L. McEdward, a Province of Alberta Graduate Scholarship to S. Carson, a Bamfield Marine Station Graduate Bursary to S. Carson, and an NSERC operating grant to F. S. Chia. We thank K. Lee-Ran, A. Martel, and G. Gibson for assistance with field collections.

\section{LITERATURE CITED}

Bayne, B. L., Gabbott, P. A., Widdows, J. (1975). Some effects of stress in the adult on the eggs and larvae of Mytilus edulis L. J. mar. biol. Ass. U.K. 55: 675-689

Bayne, B. L., Holland, D. L., Moore, M. N., Lowe, D. M., Widdows, J. (1979). Further studies on the effects of stress in the adult on the eggs of Mytilus edulis. J. mar. biol. Ass. U.K. 58: 825-841

Chia, F. S. (1976). Sea anemone reproduction: patterns and adaptive radiations. In: Mackie, G. O. (ed.) Coelenterate ecology and behavior. Plenum Press, New York, p. $261-270$

Emlet, R. B., McEdward, L. R., Strathmann, R, R. (1987) Echinoderm larval ecology viewed from the egg. In: Jangoux, M., Lawrence, J. M. (ed.) Echinoderm studies, Vol. 2. A. A. Balkema, Rotterdam (in press) 
Giese, A. C. (1959). Comparative physiology: annual reproductive cycles of marine invertebrates. A. Rev. Physiol. 21: $547-576$

Giese, A. C., Pearse, J. S. (1974). Introduction: general principles. In: Giese, A. C., Pearse, J. S. (ed.) Reproduction of marine invertebrates, Vol. 1, Acoelomate and pseudocoelomate metazoans. Academic Press, New York, p. 1-49

Hadfield, M. G. (1975). Hemichordata. In: Giese, A. C., Pearse, J. S. (ed.) Reproduction of marine invertebrates, Vol. 2, Entoprocts and lesser coelomates. Academic Press, New York, p. 185-240

Hadfield, M. G., Switzer-Dunlap, M. (1984). Opisthobranchs. In: Wilbur, K. M. (ed.) The Mollusca, Vol. 7, Reproduction. Academic Press, Orlando, p. 209-350

Hendler, G. (1975). Adaptational significance of the patterns of ophiuroid development. Am. Zool. 15: 691-715

Hermans, C. O. (1979). Polychaete egg sizes, life histories and phylogeny. In: Stancyk, S. (ed.) Reproductive ecology of marine invertebrates. Univ, of South Carolina Press, Columbia, p. 1-9

Kanatani, H. (1973). Maturation-inducing substances in starfish. Int. Rev. Cytol. 35: 253--298

Kanatani, H. (1975). Maturation inducing substances in asteroid and echinoid oocytes. Am. Zool. 15: 493-505

McEdward, L. R., Coulter, L. K. (1987). Egg volume and energetic content are not correlated among sibling offspring of starfish: implications for life history theory. Evolution (in press)

Parsons, T. R., Maita, Y., Lalli, C. M. (1984). A manual of chemical and biological methods for seawater analysis. Pergamon, New York

Reaka, M. L. (1979). The evolutionary ecology of life history patterns in stomatopod Crustacea. In: Stancyk, S. (ed.)
Reproductive ecology of marine invertebrates. Univ. of South Carolina Press, Columbia, p. 235-259

Rice, M. E. (1975). Sipuncula. In: Giese, A. C., Pearse, J. S. (ed.) Reproduction of marine invertebrates, Vol. 2., Entoprocts and lesser coelomates. Academic Press, New York, p. 7-127

Sastry, A. N. (1979). Pelecypoda (excluding Ostreaidae). In: Giese, A. C., Pearse, J. S. (ed.) Reproduction of marine invertebrates, Vol. 5, Molluscs: pelecypods and lesser classes. Academic Press, New York, p. 113-292

Strathmann, R. R., Vedder, K. (1977). Size and organic content of echinoderms and other invertebrates as related to developmental strategies and egg eating. Mar. Biol. 39: 305-309

Thompson, R. J. (1983). The relationship between food ration and reproductive effort in the green sea urchin, Strongylocentrotus droebachiensis. Oecologia (Berl.) 56: 50-57

Thorson, G. (1936). The larval development, growth and metabolism of Arctic marine bottom invertebrates. Meddr Grønland 100: 1-155

Thorson, G. (1946). Reproduction and larval development of Danish marine bottom invertebrates. Meddr Kommn Danm. Fisk.-og Havunders (Ser. Plankton) 4: 1-523

Thorson, G. (1950). Reproductive and larval ecology of marine bottom invertebrates. Biol. Rev. 25: 1-45

Turner, R. L., Lawrence, J. M. (1979). Volume and composition of echinoderm eggs: implications for the ușe of egg size in life-history models. In: Stancyk, S. (ed.) Reproductive ecology of marine invertebrates. Univ. of South Carolina, Columbia, p. $25-40$

Zar, J. H. (1974). Biostatistical analysis. Prentice-Hall, Inglewood Cliffs 